\title{
Child Sexual Abuse Dialogue: The Place of Religious Sermon Discourses
}

\author{
Clemenciana Mukenge* \\ Linguistics Department, University of Zimbabwe \\ P.O. Box MP167, Mount Pleasant, Harare. \\ Evans Chapanga \\ Linguistics Department, University of Zimbabwe \\ P.O. Box MP167, Mount Pleasant, Harare. \\ Prosper Takavarasha \\ Linguistics Department, University of Zimbabwe \\ P.O. Box MP167, Mount Pleasant, Harare. \\ Decide Miti \\ Linguistics Department, University of Zimbabwe \\ P.O. Box MP167, Mount Pleasant, Harare.
}

This research was not sponsored, it was self-funded.(sponsoring information)

\section{Abstract}

This article investigates the Apostolic Faith Mission in Zimbabwe (AFM) church's responses to the problem of child sexual abuse, through a discourse analysis of its sermons. Studies on this topic are scarce, and this study makes a modest contribution to this seemingly understudied area. AFM church was chosen as it is the oldest and fastest growing Pentecostal church in Zimbabwe. The study employs Critical Discourse Analysis (CDA) as both a framework for conceptualising the sermon discourses and a methodological thrust. In the CDA scheme, discourse is perceived to be in a dialectical relationship with social reality. A total of thirty sermons collected using the Library Research technique, and purposively sampled, were analysed using Fairclough's five-step model of data analysis. This involved identifying trends in discourse, interpreting the discourse patterns, evaluating the interpretations, drawing generalisations and lastly suggesting recommendations. It is indicated that, although religious sermons are organs of moral, social and political education, those delivered in the AFM church fail to address the horror of child sexual abuse, owing to various socio-cultural factors such as ideologies, taboos, gender inequalities and patriarchal attitudes. Recommended is the need for preachers to address this dilemma, given their power of influence in the society.

Keywords: Child Sexual Abuse; Sermon Discourse; AFM Church; Critical Discourse Analysis.

DOI: $10.7176 / \mathrm{JPCR} / 46-01$

Publication date: November $30^{\text {th }} 2019$

\section{Introduction}

In the critical discourse around child sexual abuse, the linguistic voice has remained largely muted, notwithstanding the proliferation of the stubborn scourge in various settings including the church as an institution. Children have suffered systemic sexual abuse within religious institutions, homes or schools all over the world. The common refrain amongst Christians has been to regard reportage on the sordid practice as sensationalized, especially in the context of the church. In a way, it sounds ridiculous that child sexual abuse passes off for an epidemic that is being nurtured and perpetrated even within the confines of the church. Christians cannot bury their heads in the sand and pretend the elephant in the room manifesting as child sexual abuse will just disappear. Instead, the scourge will continue to loom large in the face of prevarication, cover-ups, denial and secrecy in church communities. The greatest tragedy and most costly mistake the church can make related to child sexual abuse is to ignore its presence and reality.

Thus, the aim of this study is to investigate the Apostolic Faith Mission in Zimbabwe (AFM) church's response to child sexual abuse, focusing on the discourse of its sermons. It carries out a Critical Discourse Analysis (CDA) of selected sermons in order to ascertain whether or not this matter is addressed and how. To accomplish this aim, the study's key research question is: To what extent does the AFM church sermons address the problem of child sexual abuse and in what manner? AFM is a well established Pentecostal church in Zimbabwe, which was first launched in Gwanda, Zimbabwe, in 1915. It was chosen for this study as it is the oldest and largest Pentecostal church in Zimbabwe, referred to as the mother of Zimbabwean Pentacostalism (Maxwell, 2006 and Togarasei, 2005). 


\section{An overview of the Child Sexual Abuse Phenomenon in Zimbabwe}

Child sexual abuse includes intercourse, attempted intercourse, genital contact, fondling of genitals, exposing the child to adult sexual activity or pornography and prostitution. Horner (2010) reiterates that child sexual abuse is any sexual conduct or contact of an adult or significantly older child with or upon a child for purposes of sexual gratification of the perpetrator. Muridzo (2014) indicates that sexual abuse ranges from indecent assault to rape. The United Nations Children's Fund (UNICEF) (2015) observes that, 'child marriages represent perhaps the most prevalent form of sexual abuse and exploitation of girls'. Child sexual abuse crosses the cultural, economic and social divides. Childline (2015) estimates that approximately one in three girls and two in five boys of the world's children population are survivors of child sexual abuse. In the main, according to Mhlanga (2016) child sexual abuse "...is a national security threat on the girl child. It appears Zimbabwe is in a golden age of moral disarmament. There is moral barbarism." (p. 4).

Child sexual abuse is conceptualized better against the backdrop of who qualifies to be labelled a child, and the types, motivation and impacts of the scourge. Age of consent laws vary from jurisdiction to jurisdiction, though most of the jurisdictions set the age of consent in the range of 14 to 18 years. Statutory rape is based on the principle that a child is not capable of consent and that apparent consent by a child is not considered to be legal consent. It is instructive to note that child sexual abuse is outlawed nearly everywhere in the world with severe penalties.

Child sexual abuse (CSA) is a world-wide phenomenon (Mantula and Saloojee, 2016) and the literature on CSA is vast and includes scholarly articles and theses (Death, 2008; Munyuki, 2014; Muridzo and Malianga, 2015; Mantula and Saloojee, 2016) media articles as well as regional and global institutional reports dealing with different aspects and dimensions of the problem and solutions to the problem. According to Mantula and Saloojee (2016), the global prevalence of child sexual abuse has been estimated at $11.8 \%$, that is, 118 per 1000 children, with the highest rate in Africa (34.4\%) and lowest in Europe (9.2\%). The extent of the problem in Zimbabwe is that the country has "the ignominious distinction of being ranked amongst five countries with the highest CSA prevalence rates world-wide" (Mantula and Saloojee, 2016).

CSA cases in Zimbabwe have been mainly collected by the Zimbabwe Republic Police (ZRP) from the districts and provinces to obtain national statistics. According to the Zimbabwean police statistics, about 100 girls are sexually abused on a daily basis country-wide (Daily News, 2016 and Mantula and Saloojee, 2016). However, this is not reflective of all cases given the general lack of disclosure in the country. Child sexual abuse remains an under reported crime due to various socio-cultural reasons (Terry and Tallon, 2004; Mantula and Saloojee, 2016). What is known however, is that in well over half of the cases in Zimbabwe, the perpetrator is either related or known to the victim (Munyuki, 2014; Mantula and Saloojee, 2016 and Chakanyuka, 2017).

Motivation for child sexual abuse in Zimbabwe is varied. For example within the country and other African countries, there are some people who uphold the virgin cleansing myth that sexual intercourse with a virgin will cure a man of HIV and AIDS. In many cases sexual predators or offenders are acquainted with their victims as friends, neighbors, advisors or babysitters. Mangwana (2017:6) argues, "Our African culture allows a lot of our children to be looked after by a network of either families or people or people with familial links with the children. This is a noble 'everyone's child culture and practice. The only problem is that there are no inbuilt safeguards against abuse". The argument dovetails with the cultural practices such as the sexual orientation or socialization of in laws (chiramu). There is also the appeasing of spirits (Kuripa ngozi), where a girl child is given out to the offended as payment for crimes such as murder.

Within the context of the church there are prophetic dreams (kurotswa) in which a man may claim to have been directed by the Holy Spirit in a dream to take as wife a girl child within the sect. Muridzo and Malianga (2015:50) cites the abusive practice thus, "one claims or prophesize that he has been given a girl by the Holy Spirit", and proceed to explain yet another abusive practice of Kushandirwa in which girls with perceived health problems are, "taken by the prophet into the forest or mountain and given purportedly Holy for treatment and sexual abuse is used as one of the methods of treatment". As Kaime (2009) posits, child sexual abuse occurs within the child's environment and cultural practices do contribute to the phenomenon. Child marriage is seen as a traditional and religious rite in most parts of the world including Zimbabwe is increasingly viewed as a form of CSA with various campaigns and awareness programmes pursued by various groups (World Report on Violence and Health, 2002; Campaign to End Child Marriage, 2015).

The problem of CSA is not confined to any single denomination but occurs across faith lines within the Church (Briggs, 2010; Zhangazha, 2013). Mapimhidze (2013) argues that sexual abuse of men, women and young girls is rife in local Zimbabwean churches and Samukange (Newsday, 2014) raises the question of who will investigate sexual abuse in the Church in Zimbabwe. Further, its horrendous effects are depicted thus; "In the aftermath of CSA, families often face multiple challenges (e.g., loss of income, loss of caregiver, change of residence, and limited community support) that are often accompanied by psychological distress , such as depression, guilt, embarrassment, grief by symptomatology and secondary trauma", (Tavkor and Hansen, 2011: 189). 


\section{Theoretical Orientation}

This study is informed by Critical Discourse Analysis (CDA) as a theoretical guide for conceptualising discourse (language in use). Various CDA definitions emphasize that it is a study of the relationship that exist between texts and social structures. Fairclough, for instance defines CDA as a:

...discourse analysis which aims to systematically explore often opaque relationships of causality and determination between (a) discursive practices, events and texts, and (b) wider social and cultural structures, relations and processes; to investigate how such practices, events and texts arise out of and are ideologically shaped by relations of power and struggles over power; and to explore how the opacity of these relationships between discourse and society is itself a factor securing power and hegemony. (1993: 135).

Van Dijk agrees with Fairclough's perception of CDA and defines it as "a type of discourse analytical research that primarily studies the way social power abuse, dominance, and inequality are enacted, reproduced, and resisted by text and talk in the social and political context" (Van Dijk, 2001: 352). Scollon (2001) however does not stress on the power relations, he generally views CDA as "a program of social analysis that critically analyses discourse-that is to say language in use-as a means of addressing social change" (p. 140).

Given its multiple disciplinarity, there are three main theoretical directions in CDA: van Dijk's socialcognitive model, Wodak's discourse-historical model and Fairclough's three-dimensional theoretical framework. This study is interested in Fairclough's approach that perceives a dialectical relationship between language and social reality as represented through social events (texts), social practices (orders of discourse) and social structures. It draws on social theories of discourse as well as linguistic theories in developing a "threedimensional theoretical framework" of textual analysis that studies the communicative event (text) through analyzing the interrelationship between discourse and social structures. As such, Chuliaraki and Fairclough (1999) posit that CDA "brings social science and linguistics...together within a single theoretical and analytical framework, setting up a dialogue between them" (p. 6).

Discourse as text, is the first dimension in Fairclough's three-dimensional model for CDA. This studies why a text is designed in a certain manner and to what effect, through an examination of the linguistic choices of the text, determining the function of these textual features in constructing or rejecting ideological schemes and power inequalities. The second dimension, is discourse as discursive practice, which examines the process of text production, its distribution and consumption. It emphasizes the interdependency of texts to other texts, referred to as intertextuality. Intertextuality "is basically the property texts have of being full of snatches of other texts which may be explicitly demarcated or merged in, and which the text may assimilate, contradict, ironically echo, and so forth" (Fairclough, 1992: 84). The third dimension, discourse as social practice, is concerned with socio-cultural practices of the text in relation to context, particularly drawing on the concepts of ideology, power and hegemony to demonstrate the role of discourse in maintaining or transforming disparate power relations. It also acknowledges that the textual selection is historically and contextually bound. Hence, texts are conceived as socially regulated discourses whose processes of production and reception are socially conditioned.

The three dimensions discussed above constitute Fairclough's three analytical focuses that are significant in analysing any communicative event (text), and that demand a distinct method of analysis. Accordingly, the text requires a descriptive analysis; text production/reception processes need an interpretative analysis and the sociohistorical contexts analysis involves explanations. Fairclough's approach to CDA is significant as it provides multiple interrelated levels of textual analysis (text description, process interpretation and social explanation) which comprise a comparatively in-depth exploration of a specific text. Another significance of this approach to this study is that it allows the researchers to focus attention on signifiers and linguistic choices that constitute the text (that is, the studied sermon discourses).

\section{Methodology}

Data

The data for this study is composed of the corpus of thirty sermons falling under five themes, that were delivered at Sunday Services spanning over a period of six months (December 2018 to May 2019), in AFM church situated in Harare. This data comprises of verbal words, phrases and sentences, uttered as part of the sermon conveyances. The choice of sermons was informed by their moralizing quality, typical of the sermons that were delivered during the studied period. fact that during the first half of the year, the themes for preaching were focused on moralizing and were most likely to address the matter of child sexual abuse at hand. Also, efforts to retrieve earlier recorded sermons proved futile as a result of loss of record. Six months is an ample and empirical timeframe to track and trace the trends of language matters addressed in sermons by a preacher. Sermons are a common foundation of preaching in the Pentecostal churches, and hence are useful sources of information concerning the religious doctrines and teachings. The AFM church was selected due to its recent growth amongst Pentecostal churches in Zimbabwe. In addition, it was easy to obtain recorded sermons as the church keeps records of all the sermons. One major weakness of recorded data as well expressed by Patton (2001) is that it 
fails to present the natural flow of language. Nevertheless, this was not an issue for this study given that this is a non-pragmatic analysis, and hence natural language use is not important.

\section{Sampling Method}

Generally, there are three key methods of sampling in qualitative studies; opportunistic (or convenience), theoretical and purposive sampling (Burns and Grove, 2001). The study sample was collected using the purposive sampling technique, also known as judgmental sampling. As the term signals, according to Streubert and Carpenter (1999), a purposive sample is a non-probability sample, selected based on characteristics of a population as well as the aim of the study. As Patton (2001) rightly observes, purposeful sampling is useful as it allows the researcher to select only rich information for study purposes. It is also useful as it is shaped by the interests and aims of the study, thereby enhancing effective delimitation of the scope of qualitative studies (Schatzman and Strauss, 1973). In this study, purposive sampling involved the selection of sermons strictly based on their subject matter and themes. Only those that fall under themes that are relative to teachings on selfconduct, behavior and community issues were selected. Five key sermon themes were chosen; Power of Victory, When God remembers, God's Presence, The party is Over, Those who walk with God.

\section{Data Collection}

A qualitative research method was employed to collect secondary data for the study. This involved library research that enabled the researchers to retrieve DVD Sermons from the AFM church library in Harare. Library research is a form of data collection technique that involves a step by step process for gathering data. The process involves identifying and locating relevant information, analysing the information and then developing and expressing ideas deriving from the analyses (Young, 1983). In this study, the three steps were accomplished by firstly identifying the type of information needed for the study, that is AFM recorded sermons, followed by locating and visiting the library where these are kept. Analysing the information involved presenting it in thematic categories, and then interpreting it using CDA tools in order to derive new ideas. This method was useful as it allowed the researchers to control the direction and the pace of the study.

\section{Data Analysis}

Data analysis was carried out using Fairclough's (2001) five-step model for textual analysis. The first step is a "focus on the social problem which has a semiotic aspect" (Fairclough, 2001: 125). In this study, the problem is that of lack of engagement of the problem of child sexual abuse. The second step involves "identifying obstacles to resolving the problem being tackled..." (Fairclough, ibid). This is the most essential step of CDA analysis where crucial interpretive analyses are carried out and hence interpretive arguments are built based on social realities. The third step is to "consider whether the social order (network of practices) in a sense 'needs' the problem" (Fairclough, 2001: 125). The fourth step is "identifying possible ways past the obstacles" and the fifth and final step is "critically reflecting on the analysis carried out from step one to four" (Fairclough ibid). These last two steps in CDA analysis do not involve analyses of text, but require the researcher's contribution through suggesting resolution strategies to the problem of the study based on conclusions made.

Guided by Fairclough's model, data analysis involved firstly transcribing verbal data from recorded sermons which were delivered mostly in Shona and English, and then translating the data into English. This was followed by data interpretation, which encompassed identifying specific topics within the broadly themed sermon texts and delineating the scope of the sermon discourse. The matters embedded in the identified topics were then analysed in order to determine whether or not the dare topic of child sexual abuse is addressed, and the linguistic strategies used, given the sensitive matter of the subject in the Zimbabwean context. This task was key for answering the main research question raised in the beginning.

\section{Data Presentation}

Data collected through the library research method to investigate the manner in which the problem of child sexual abuse is addressed in the sermons delivered in the AFM church in Zimbabwe, reveals that the discourse of the sermons revolves around various topics. These findings are presented in this section, under five themes. Under each theme, there are various sub-topics that constitute titles for sermons that were delivered every Sunday over the studied period. The themes for the AFM preaching derive from the activities that take place in the church during the course of the year. For instance, from the first of January to the tenth its prayer and fasting period and thereafter up until March its a period to explain, interpret and teach various doctrines and laws of the church. A series of conferences begins in April where there is National Youth Conference, followed by National Ladies conference, August National General Conference, General Quarter conference at provincial level, Youth conference and the Single ladies conference. In addition, in the last service of every third month of the year, the message is centred on appreciation. Then there is also a separate month for appreciation once every four months, and towards the end of year there is the pastor's Christmas. Further, after every National Conference the 
preaching for the next two weeks or so is focused on the previous conference. Sermons are therefore influenced by these activities. The following is an outline of the linguistic content of thirty sermons that were delivered under five broad themes, from December 2018, to May 2019, focusing on the subject matter and discourse patterns.

\section{The Power of Victory}

'The power of victory' is the main theme within the AFM church which opened the preaching season in the new year, comprising of six sermon topics delivered within six weeks. It centralises and captures the spiritual foundation of the church, based on the fight between good and evil. Under this theme, various issues are discussed that capture how spiritual victory can be achieved, methods of retaining that victory and ensuring future victories. The first sermon is on 'Participation in church, Fighting against enemies, and other contrary religions'. According to this sermon, the power of victory emanates from individual participation within the church and declaring a spiritual fight against the enemies (referred to as satanic forces) through prayer and fasting. In addition, the audience is summoned to remain faithful to its religion and rid all other religions that are contrary to its own. The second sermon addresses the issue of 'Weddings' which are said to be meaningless ceremonies as opposed to marriages. The congregates are reminded to focus on the life-long journey of the marriage, rather than the wedding ceremony which is a mere day event. The third sermon is delivers a message on 'Doing the word of God'. According to this preaching, it is the task of every individual to spread the word of God, especially to those who haven't repented. In turn individual behaviour needs to be shaped by the Biblical teachings.

Another sermon delivered under the theme of 'The power of victory' is entitled 'Existence of enemies amongst church members'. The thrust of this sermon is to caution the congregation that not everyone is upright in the church, people may have varied intentions and it is the duty of the church to be cognizant of such deceptive characters. The topic of 'Forgiveness' is dealt with within the fifth sermon where the church members are reminded about the power of forgiveness. According to the sermon, forgiveness is more beneficial to those who provide than those who receive as it free both the mind and spirit of individuals. The last sermon within the theme of 'The power of victory' is 'Developing a relationship with God'. This focuses on teaching about the general importance of knowing God. The relationship with God is depicted as a perpetual method for securing spiritual victory through His protection and love.

When God Remembers You

There are five sermons delivered under the theme "When God Remembers You". These predominantly urge the congregants to behave in a particular desired manner so as to be remember by God in mercy. The first sermon addresses the topic 'The power of prayer', relating to how prayer can benefit not only the individual, but the nation as a whole. In this sermon, there is emphasis of prayer as a prerequisite for God's remembrance of His people, hence the audience is encouraged to become 'servitude' to prayer. Another sermon under the same theme explored the topic of 'Crossing over from all the problems.' This topic is sequential to God's commemoration of His people, addressed in the previous sermon and is in line with the Christian faith-based belief that God answers prayers. The main message in this sermon is that through prayer people are able to transcend from hardships and suffering, as God always takes heed of their prayers. The third sermon tackles the subject of 'Qualification for God's blessings', where the audience is encouraged to live the Christian way, in addition to prayer. The sermon teaches the lesson that not everyone qualifies to receive God's blessings, there is need to work towards this privilege. There is emphasis on the existence of a hierarchy for obtaining God's favors, where those living a life of chastity reside at the top, and are closer to God than the rest.

As follow up to the previous sermon that addresses the issue of qualifying for God's blessing is the notion of 'Marriage', discussed to exemplify life of purity. Prominent in this sermon is faithfulness in the matrimonial relationships, rendering marriage as ideally the pinnacle of extensive source of morality. In this vein, congregants are strongly warned to respect the matrimonial vows and to love one another in order to gain God's favor. In another sermon, the topic of 'Discouraging issues and effects of jealous' is explored as another example of living a life of wholesomeness. In this sermon, the audience is encouraged to discard feelings of jealousy and lust towards one's own neighbour as jealousy is an act of evil. Christians are also invigorated to overlook jealousy behaviour enacted against them by others, as these may be weapons used against them by the devil.

\section{God's Presents}

Sermons delivered under the theme 'God's presents' basically dwell on aspects related to rewards and benefits of being faithful and affiliated to God. The rewards are both materialistic and spiritual. The first sermon delivered under this theme is about 'Walking with God'. This sermon lays foundation on the precondition for receiving God's presents, which is 'walking with God'. According to the preaching, this entails allowing God into one's life through repentance and prayer. Once God has entered one's life, that individual would receive 
protection and would be blessed abundantly. The following sermon, 'Men, money and small houses (infidelity)', makes provision for the presents that are likely to be gained through closeness with God, and warns of the likely temptations that may follow God's presents. Men in particular, are strongly advised to continue to seek God once they come across riches and possessions, as riches without God's guidance would lead to misuse of funds and eventual impoverishment. They are also warned against straying from their marriages, 'small houses' (girlfriends) and infidelity in general, as these would lead to withdrawal of God's blessings.

In the same breath, another sermon is dedicated to the subject 'Witchcraft'. Here, the audience is warned against witchcraft, described as a spirit of destruction which is non-beneficial to both the perpetrator and the victim. Thus, witchcraft is depicted as a destructive, yet useless practice which needs to be rid of. Moreover, in the sermon 'Seek God's favour', believers are warned to abandon evil ways and live a straight life in order to acquire favour from God. The teachings in this sermon are in line with those of 'Walking with God' sermon where the preacher is mainly inciting alignment with God. In the last sermon under the theme of 'God' presents', entitled 'Blessings', the preacher presents a closing admonition to encourage the congregates to repent so as to earn the greatest present of all, God's blessings. It concludes all the discussions raised in the sermons delivered under this theme by overtly suggesting that the benefit of seeking God, living with and through Him is receiving His blessings, an aspiration of all the Christians.

\section{The Party is Over}

As the title signals, eight sermons under the theme 'The Party is Over' (delivered over a period of two months) predominantly address the need to forgo bodily pleasures and focus on spiritual fortification. The first sermon is entitled 'God against gods', embarking on the contest between Christianity and idolatry. The worship of idols and other gods beside God is condemned as these are evil invocations. Religious fanaticism is portrayed as a feature of African religion where gods and idols are implored in order to counter life challenges. The substance of this sermon is that Christians should serve only one God. The second sermon 'God's timing', teaches about the virtue of patience where Christianity is concerned given that things are done according to God's time and plan. It is also emphasised that blessings come and prayers are answered at God's time, and that His time is best. The topic of the third sermon under this theme is 'Victory over the devil and demons'. In this sermon, there is signal towards the war between good and evil, where God remains the victor. The moral behind the sermon is that Christians would always be tempted and challenged by the devil as long as they live according to God's law, and hence should always be prepared.

The fourth sermon is based on the subject of 'Prostitution', a problem associated with demon possession. Prostitution is discussed in reference to those women who are engaged in extra-marital affairs, and those who have more than one partner, perceived as demonic and the devil's weapons used to cause pain and suffering. The fifth sermon details the topic of 'Drug abuse', a problem depicted as another unwarranted bodily indulgence amongst male youth, that acts against God's will. According to the preaching, drugs are an invention of the devil whose target is to destroy God's people. There is therefore a strong call to desist from using drugs. 'Repentance and Heathen' is the subject of the sixth sermon. The moral of this sermon is to make the right choice between two paths; repentance and heathen way of life. In bid to assist the audience to make that choice, the preacher outlines the benefits of repenting (which involves receiving God's grace and blessings) and the effects of heathen life (incorporating lack of knowledge of God, leading to eventual spiritual isolation and suffering). The seventh sermon is about 'Caring for the man of God'. This sermon is mainly a follow up to repentance in which the preacher prescribes how Christians should live after repentance, caring for one another. This is considered as an important task that is bestowed on every born again Christian, so that they do not revert to the life of uncleanliness. The last sermon under the theme of 'The party is over', is entitled 'Demons'. In this sermon, the meaning of 'party is over' revolves around the eradication of demons from Christian's lives. The demons are portrayed as the cornerstone of all societal problems and evils. They are depicted as manifesting in individuals through behaviour which is ungodly, resulting in chaos, illnesses and deaths in the society. In conclusion, congregants are warned to get rid of the demons that are causing confusion in their lives through seeking God.

Those who walk with God

The title of the last theme of sermons studied in this article is 'Those who walk with God'. There are seven sermons that were delivered under this theme within a period of seven weeks. The first sermon is based on the topic 'Attracting God's blessing, protection and favor', corresponding with the previous one on 'Blessings'. The content of these two sermons is similar, focusing on how Christians can behave in order to command God's blessings. Amongst the prescribed sets of behaviour is seeking forgiveness and repentance, prayer, staying away from sinful ways and co-existence with others. 'New order' is a sermon that relates on how repentant people can live in the society. New ways of doing things include shunning old sinful ways, steadfast prayer and fellowship with others, which entails 'new order'. 
The third, fourth and fifth sermons engage Bible stories to explore the theme of 'Those who walk with God': 'The transition of power between Moses and Joshua'; 'The anointing of David herding sheep' and 'David protected the sheep from hyenas and lions'. The main thrust of the messages in these three sermons is that, God empowers those who follow Him, even the underdogs and outcasts who are looked down upon by others. Secondly, God will always reward those who follow Him, he will protect His own people, hence people should choose wisely concerning the paths of life. The sixth sermon is on the topic 'The power of anointing', relating to the importance of spiritual rebirth for congregates, through anointing. In this sermon, which is based on the church doctrine anointing, it is indicated that, it is not enough to fellowship with others, each and every member of the church should receive anointing so that they become fully recognized members of the denomination. The topic of 'Marriage' comes as the final sermon under the theme of 'Those who walk with God', and reiterates the same subject tackled under the theme 'When God remembers You'. In this sermon, both men and women are encouraged to respect and be faithful to one another. The woman is reminded to humble herself below her husband, and the husband to submit to the church as according the teachings of the Bible.

The data presented above indicates that the dominant topics discussed in AFM church sermons are marriage and God's blessings. Whereas these key societal issues are discussed in the religious sermons, the subject of child sexual abuse seems to be absent, overtly or covertly. In fact, it revealed that any matters that have to do with children are not topical. Children are mentioned only as part of a matrimonial home, when marriage and fidelity issues are concerned.

\section{Data Analysis}

As noted in the introduction, the purpose of this study is to explore the manner in which the topic of child sexual abuse is addressed within the discourse of sermon delivered in the AFM church, informed by the urgency of the matter which has resulted in serious health problems in Zimbabwe. From the data presented above, it is apparent that the problem of child sexual abuse is overlooked in the AFM sermons, although sermons are believed to be the organs of socio-political and moral education, achieved through effective use of language (Esimaje, 2012). The topics discussed in these sermons appear to be ideologically inclined, mainly discussed to pursue the church's doctrines, values, interests and beliefs. "Ideologies are fundamental beliefs of a group and its members" (van Dijk, 2004: 7). Van Dijk explains that:

One of the crucial social practices influenced by ideologies are language use and discourse, which in turn also influence how we acquire, learn or change ideologies. Much of our discourse, especially when we speak as members or groups, expresses ideologically based opinions. (2004: 9).

Thus, taking lead from van Dijk's view of the discursive relationship between discourse and ideology, it is apt to argue that the charisma of Pentecostalism is channelled to communicate issues that support the views and interests of the church. For example, it is clear from the data presented above that the main subjects discussed in the sermons at the beginning of the year are forgiveness, seeking a relationship with God, and repentance, which coincide with the period of fasting and prayer within the church. Given that the topics tackled by the preachers are influenced by the social structures of the church, it is not surprising that child sexual abuse is excluded as it has no place in the scheme of things of the AFM church. Biri (2013) rightly observes that the Zimbabwean Pentecostals are preoccupied with "...promoting their own specific denominations and activities..." (p. 23) and have used their sermons "...to perpetuate their evangelistic agenda..." (p. 26), in order to gain recognition as a global phenomenon.

Self-promotion coupled with ideologically orientated messages is explained by some critics as depicting religious materialism, which typifies the Pentecostal churches in Zimbabwe and elsewhere (Biri, 2013). On religious materialism, Uka (2001: 4) quoted in Biri (2013: 22) explains that: "Pentecostals in Zimbabwe believe that successful secular activities and spiritual strivings are not antithetical and they have successfully blurred the boundary between the spiritual and the material, the religious and the economic." As a result, and as clearly demonstrated in the findings of the study, the messages delivered in the AFM sermons are typical of what Oyedepo (1997) refers to as the 'gospel of prosperity', a controversial theme in contemporary Christianity. The prosperity messages advocate for financial blessings, good health and detail God's plan for men (Oyedepo, 1997). Thus, whereas the sermons are used to proclaim the gospel of wealth and prosperity, urgent social realties tend to be side-lined, and in this case the critical matter of child sexual abuse in Zimbabwe.

The deafening silence surrounding the issue of child sexual abuse in the church and the society at large in Zimbabwe could also be ascribed to a number factors that hinder the freedom to comment on this atrocity. In this context, according to Brazelton (2015), attempts to engage in the child sexual abuse topic and disclosure processes are "shaped by relational, racial, socio-cultural, historical and developmental factors" (p. 182). Thus, the church, a social institution, also seems to be regulated by these constraints in its efforts to address the challenge of sexual abuse. On the socio-cultural front, the discourse of child sexual abuse represents a serious social taboo, given firstly the innocence of the child followed by the offensiveness of the subject of sex itself, especially in the public domain. The very tabooed nature of the subject of child sexual abuse represent a barrier 
for its open discussion, thereby frustrating any attempts to resolve this problem at a societal level.

In corroboration with the view of cultural taboos raised above, AFRUCA (2015) posits that child sexual abuse is indeed characterised by a culture of shame, secrecy, stigma and silence which has resulted in lack of knowledge and clarity of this issue in societies. Mugawe and Powell (2006) explain that, owing to the secrecy surrounding child sexual abuse especially in African countries, it is difficult to establish its record, since the reported cases down play the reality. Thus, whereas the church is expected to be the moral voice through preaching and sermon messages, ironically, it is silent about the social ill of child sexual assault, indirectly enabling the perpetrators. The church's dilemma rests in the fact that its religious discourse is shaped by existing social-culturally defined beliefs, views, perceptions and values that uphold child sexual abuse as an unspeakable abomination. These beliefs according to Fairclough (1992) are in turn socially constituted as they are influenced by the social structures that they define.

The predicament of the silence surrounding child sexual abuse in Zimbabwe by the church and the society as a whole can also be viewed from the point of view of gender. In this argument, gender inequality and male dominance is associated to the concealment of child sexual abuse in order to protect the image of the dominant male figures in the society. On gender inequality Mashiri (2013) argues that it is a catalyst for gender based violence. In Zimbabwe violence against women is perceived as a socially sanctioned problem that impinges on human rights and has so far imposed developmental problems, which are also felt at a global scale.

Fontes and Plummer (2010) add that patriarchal attitudes and devaluation of women in African societies are some of the cultural barriers that impede confrontation of child sexual abuse. Patriarchy refers to "the rule by male head of social family were a societal elder has legitimate power over others in the social unit which is mainly the family" (Mashiri, 2013: 94). Patriarchal structures are therefore responsible for intensifying gender inequalities and stimulating male supremacy and women subordination. In such contexts, women are unable to stand up for their rights and are hindered from seeking legal recourse when abused, as they dread to lose family income and support or even being tainted by social stigma associated with abuse (Mashiri, 2013). Fontes and Plummer (2010) agree that culturally based beliefs systems foster environments within which children and family members fail to disclose child sexual abuse in fear of rejection. In essence, it is argued that the church fails to address the problem of child sexual abuse as it is also bound by these cultural barriers and stipulations, manifested in male dominance and patriarchal tendencies. Given that pastors are social beings, they understand and live by the norms of the society, which in this case espouse male superiority, it is not surprising that instead of challenging masculinities which violate young girls, in most cases, they choose to preserve their silence, so as avoid rejection.

Further, a sensitive issue such as child sexual abuse is likely to be handled well in one on one dialogical contexts, where a discussion of abuse or prevention is initiated (Jensen et al., 2005 and Ungar, 2009). This entails that in a church where congregants are gathered, a public address of this matter becomes cumbersome. A public address of child sexual abuse is likely to break Grice's (1975) maxim of relation, that specifies that the speaker should be relevant and say things that are pertinent to the discussion, to achieve cooperation avoid offence and irrelevance. As explained by Ungar (2009), addressing this subject matter warrants appropriateness, relevance as well as protection of both the speaker and hearer, which has to do with saving face, given that it is a face threatening subject.

Nevertheless, although the studied religious sermons fail to capture the pertinent issue of child sexual abuse, some key societal concerns are discussed such as prostitution, drug abuse and witchcraft. This points to the fact that the inability to discuss child sexual abuse is inherent in the subject itself. It is not a an ordinary matter that can be easily voiced in the public, it is however greater than the silence it embodies. Also, in support of this view, it is not only the church that fails to confront the challenge of child sexual abuse, at least in public, but also various other social institutions. The judiciary system for example which is expected to exert more power than in the society is docile when it come to this issue seen in somehow apologetic terms such as 'indecent assault' for sexual abuse. The law enforcers such as the police also display a meek attitude towards dealing with the matters of sexual abuse, mostly dismissing them as a domestic violence cases, yet they are in reality criminal offences that warrant corporal punishment. The church thus appears to endorse the existing attitudes in the society that trivialise the problem of child sexual abuse.

\section{Conclusions and Recommendations}

This critical discourse investigation of data samples of sermons delivered in the AFM church in Zimbabwe establishes three focal point. Firstly, it suggests that child sexual abuse is not a topical concern in this denomination. The subject matter holds absolutely no place in the church's preaching activities. In the same breath, the study establishes the fact that the church is not necessarily a source of moralisation, as widely assumed, given that it fails to interrogate the problem of child sexual abuse, a current health concern in Zimbabwe. Secondly, preachers in the Pentecostal church appear to favour discourse of materialism which proclaims the gospel of wealth and prosperity, overlooking some pertinent issues in the society, such as child 
sexual abuse. Thus, the preacher's discursive practices in the sermons can be productive in addressing the goals and expectations of the church, which has implications for choice of language form and content. In essence, although the sermon is an expressive vehicle in which language plays a crucial role in achieving desired effects, it is ideologically inclined, serving the interests of the church and its stakeholders. Thirdly, failure to grapple with the issue of child sexual abuse in the church can be attributable to socio-cultural constraints such as taboos that give rise to shame and stigma associated with public sex discourse, as well as predominant patriarchal attitudes that demean women.

Recommended is the immediate need for preachers to embrace the role of engaging their audiences on the predicament of child sexual abuse since these are influential and have the power to modify behaviours. This is not to overlook the problem of taboo, various euphemistic strategies may be employed to avoid offense and to save face. In addition, since there are no active platforms for openly speaking about the dilemma of child sexual abuse, there is need for the people responsible for the child such as parents, teachers, health practitioners, traditional healers and the society at large, to break the silence and speak out against this social ill. Speaking out against child sexual abuse is key for its eradication in Zimbabwe, where it thrives as a result of its existence in the shadows, figuratively explained as 'hidden in plain sight' UNICEF (2015).

\section{References}

African Union Campaign to End Child Marriage (2015). The Effects of Traditional and Religious Practices of Child Marriage on Africa's Socio-Economic Development: A Review of Research, Reports and Toolkits from Africa.

AFRUCA (2015) Child Sexual Abuse in the African Family Context [Online]. www.afruca.org. (Accessed $11 / 06 / 19)$.

Aljazeera. (2019). Pope Francis orders priests and nuns to report sex abuse. (New Zimbabwe, 10 May 2019). Available at: https//newzimbabwe.com/pope-francis-orders-priests-and nuns-to-report-sex-abuse/ (Accessed: 11 May 2019).

Biri, K. (2013) Religion and Emerging Technologies in Zimbabwe: Contesting for Space? International Open and Distance Learning Journal. 1(1): 19-27.

Brazelton, J. F. (2015). The secret storm: Exploring the disclosure process of African American women survivors of child sexual abuse across the life course. Traumatology: An International Journal, 21, 181-187.

Briggs, D. (2010). Sexual abuse of children crosses faith lines. Available at: http://blogs.thearda.com/trend/featured/sexual-abuse-of-children-crosses-faith-lines/ (Accessed 24 April 2019).

Burns, N. and S. K. Grove. (2001). The Practice of Nursing Research. Philadelphia: Saunders.

Cahill, D. (2018). Rebuilding Pastoral Health and Integrity after the Royal Commission into Institutional Responses to Child Sexual Abuse. Available at: http://religionsforpeaceaustralia.org.au/wpcontent/uploads/2018/09/and-What-Would-God-Think.pdf (Accessed 24 April 2019).

Childline (2015). Child sexual abuse. Poster, Harare, Chldline.

Chitando, E. and Chirogoma, T. (2013). Justice Not Silence: Churches facing sexual and gender-based violence. Institute for Theological \& Interdisciplinary Research. Pretoria: Sun Press.

Chitando, E., Gunda, M. R. and Kugler, J. (2013). Prophets, Profits and the Bible in Zimbabwe. Festschrift for Aynos Masotcha Moyo. Bamberg: University of Bamberg Press.

Chouliaraki, L. and Fairclough, N. (1999). Discourse in Late Modernity: Rethinking Critical Discourse Analysis. Edinburgh: Edinburgh University Press.

Church and Civil Society Forum, (2012). A Study on the Role of the Church in Violence in Zimbabwe. Harare: The Church and Civil Society Forum (CCSF).

Death, Jodi. 2008. Forgiveness, Power and Child Sexual Abuse by Church Leaders in Australian Churches. [PhD Thesis].

East, Central and Southern African Health Community (2011). Child Sexual Abuse in Sub-Saharan Africa: A Review of the Literature.

Eggins, S. (2005). An Introduction to systematic Functional Linguistics, $2^{\text {nd }}$ Edition, Continuum.

Esimaje, A. U. (2012) A Corpus-based Lexical Study of Sermons in Nigeria. English Language Teaching, 5(9): 24-32.

Fairclough, N. (1992). Discourse and social change. Cambridge: Polity Press.

Fairclough, N. (1993). Critical Discourse Analysis: The Critical Study of Language. London: Longman.

Fontes, L. A. and Plummer, C. (2010). Cultural issues in disclosures of child sexual abuse. Journal of Child Sexual Abuse, 19, 491-518.

Grice, P. (1975). Logic and Conversation. In P. Cole and J Morgan (eds.). Syntax and Semantics 3, New York: Academic Press.

Groff, A. (2017). Child abuse prevention starts with your church. The Mennonite Features Posts. 
https://themennonite.org/feature/child-abuse-prevention-starts/ (Accessed 16 May 2019).

Halliday, M.A.K. (1975). Learning to mean- Explorations in the development of language , London, Edward Arnold.

Horner, G. (2010). Child sexual abuse: Consequences and Implications. Journal of Pediatric Health Care, 24 (6), 358-364.

Jensen, T. K., Gulbrandsen, W., Mossige, S., Reichelt, S., \& Tjersland, O. A. (2005). Reporting possible sexual abuse: A qualitative study on children's perspectives and the context for disclosure. Child Abuse \& Neglect, $29,1395-1413$

Kaime, T. (2009). The African Charter on the Rights and Welfare of Child; A socio-legal perspective, Pretoria, Pretoria University Press.

Mangwana, N. (2017). View from Diaspora, The role culture plays in child rape. [The Herald, 12 September 2017]. Available at: https//www.herald.co.zw//.the-role-culture-plays-in- child-rape/ (Accessed: 10 May 2019)

Mantula, Fennie and Saloojee, Haroon. (2016). Child Sexual Abuse in Zimbabwe. Journal of Child Sexual Abuse, 25:8, 866-880, DOI. Available at http://dx.doi.org/10.1080/10538712.2016.1234533. (Accessed 10 May 2019).

Mapimhidze, Ropafadzo. (2013). Sexual abuse rife in local churches. (Newsday, January 12, 2013).

Mashiri, L. (2013). Conceptualisation of gender based violence in Zimbabwe. International Journal of Humanities and Social Science. 3 (15), August 2013.

Maxwell, D. (2006). African gifts of the spirit: Pentecostalism and the rise of a Zimbabwean transnational religious movement. Harare: Weaver Press.

Mhlanga, J. (2016). Child sexual abuse in Zim: Call for action. (Newsday, September 23, 2016).

Mhlanga, J. (2016). Child sexual abuse in Zim: Call for action. [Daily News, 23 September 2016]. Available at: https//www.herald.co.zw//child-sexual-abuse-Zim-call-action/ (Accessed: 10 May 2019).

Mugawe D and Powell A. (2006). Born to High Risk: Violence Against Girls in Africa. Addis Ababa: The African Child Policy Forum.

Muridzo, N. G. and Malianga, E. (2015). Child Sexual Abuse in Zimbabwe: Prevention Strategies for Social Workers. African Journal of Social Work, 5(2), December 2015.

Muridzo, N.G. 2014. Child Sexual Abuse in Zimbabwe, An Agenda for Social Work, The Journal of Social Work, 75 (1), 49-68.

Muridzo,N.G and Malianga, E. (2015). Child sexual abuse in Zimbabwe: Prevention Strategies for Social Workers, African Journal of Social Work, 5 (2), 49-61.

Oyedepo, D. O. (1997) Understanding Financial Prosperity, Ikeja: Dominion Publishers.

Patton, M. Q. (2001). Qualitative Research and Evaluation Methods. California: Sage Publications, Incorporated.

Radford, L. Allnock, D. and Hynes, P. (2015). Preventing and Responding to Child Sexual Abuse and Exploitation: Evidence review: UNICEF.

Radford, L., Allnock, D. and Hynes, P. (2015). Promising Programmes to Prevent and Respond to Child Sexual Abuse and Exploitation: UNICEF.

Royal Commission into Institutional Responses to Child Sexual Abuse. (2017). Final Report: Religious institutions. Volume 16 Book 1.

Royal Commission into Institutional Responses to Child Sexual Abuse. 2017. Final Report: Religious institutions. Volume 16 Book 2.

Samukange, T. (2014). Who will investigate sexual abuse cases in churches? (Newsday, February 24, 2014)

Schatzman, L. and Strauss, A. L., (1973) Field Research: Strategies for a Natural Sociology. Englewood: Prentice-Hall.

Scollon, R. (2001). Action and text: towards an integrated understanding of the place of text in social (Inter)action, mediated discourse analysis and the problem of social action. In R. Wodak and M. Meyer (eds.). Methods of Critical Discourse Analysis, London: Sage Publications: 139-183.

Streubert, H. G. and Carpenter, D. R. (1999). Qualitative Research in Nursing. Philadelphia: Lippincott.

Tavkor, P and Hansen, D. J. (2011). Intervention for families victimized by child sexual abuse: Clinical issues and approaches for child advocacy centre based services, Aggression and violent behaviour, 16 (3), 188-199.

Terry, K. and Tallon, J. (2004). Child Sexual Abuse: A Review of the Literature.

Togarasei, L. (2005). Modern Pentecostalism as an urban phenomenon: The case of the Family of God Church in Zimbabwe. Exchange: Journal of Missiological and Ecumenical Research 35(4): 349-375.

Ungar, M., Barter, K., McConnell, S. M., Tutty, L. M., and Fairholm, J. (2009). Patterns of abuse disclosure among youth. Qualitative Social Work. 8, 341-356.

UNICEF (2015) Ending Child Marriages (Progress and Prospects). http://www.unicef.org/media/files/childmarriages-Report-7-17-LRpdf. (Accessed 12/6/19).

United States Catholic Conference (1995). Walk in the Light: A Pastoral Response to Child Sexual Abuse. 
Available at: http://www.usccb.org/issues-and-action/child-and-youth-protection/walk-in-the-light.cfm (Accessed 25 April, 2019).

Van Dijk, T. (2001). Critical discourse analysis. In D. Schiffrin, D. Tannen and H. E. Hamilton (eds.). The Handbook of Discourse Analysis. Oxford: Blackwell Publishing: 352-372.

van Dijk, T.A. (2004). Politics, ideology and discourse. Retrieved May 20, 2019. from http://www.discourse-insociety.org/teun.html.

Vinga, A. (2014). Child sexual abuse victims locked up in psychological prisons. (Newsday, June 21, 2014).

Young, H. (1983). ALA Glossary of Library and Information Science. Chicago, IL: American Library Association.

Zhangazha, W. (2013). Sexual abuse of children is not just a Vapostori issue. In the Churches Blog, AllAfrica.com. 